\title{
Parambassis waikhomi, a new species of glassfish (Teleostei: Ambassidae) from Loktak Lake, northeastern India
}

\author{
K. Geetakumari ${ }^{1} \&$ C. Basudha ${ }^{2}$ \\ 1,2 ICAR, Research Complex for NEH Region Manipur Centre, Lamphelpat Imphal, Manipur 795004, India \\ Email: ${ }^{1}$ geetameme@gmail.com (corresponding author), ${ }^{2}$ devibasu@yahoo.com
}

Freshwater glass perches of family Ambassidae are small to medium-sized semi transparent fishes which are extensively consumed by larger fishes. Currently, the family comprises of four genera namely Chanda, Gymnochanda, Paradoxodacna and Parambassis (Roberts 1994). Fishes of the genus Parambassis Bleeker are characterized by 30-100 scales in lateral series, 9-16 dorsal and anal fin rays, $10+14=24$ or $10+15=25$ vertebrae, preorbital bone with serrations on ridge and edge comprising a diverse and possibly polyphyletic array of strictly freshwater ambassids widely distributed in the Indian subcontinent mainland and peninsular Southeast Asia and the Australian region including New Guinea (Roberts 1994). As many as 12 species of Parambassis of Asia are currently treated valid (Roberts 1994; Kottelat 2003) of which five are

Date of publication (online): 26 November 2012

Date of publication (print): 26 November 2012

ISSN 0974-7907 (online) | 0974-7893 (print)

Editor: Neelesh Dahanukar

\section{Manuscript details:}

Ms \# 03060

Received 09 January 2012

Final received 18 October 2012

Finally accepted 01 November 2012

Citation: Geetakumari, K. \& C. Basudha (2012). Parambassis waikhomi, a new species of glassfish (Teleostei: Ambassidae) from Loktak Lake, northeastern India. Journal of Threatened Taxa 4(14): 3327-3332.

Copyright: () K. Geetakumari \& C. Basudha 2012. Creative Commons Attribution 3.0 Unported License. JoTT allows unrestricted use of this article in any medium for non-profit purposes, reproduction and distribution by providing adequate credit to the authors and the source of publication.

Acknowledgements: The authors are grateful to Prof. W. Vishwanath, Department of Life Sciences, Manipur University for his valuable help. We are also thankful to P. Musikasinthorn and T. Roberts for providing literature. The first author records her thankfulness to Department of Biotechnology for financial assistance for DBT-RA programme.

urn:Isid:zoobank.org:pub:FD88B901-64DE-42AA-91A8-903014706048

\section{OPEN ACCESS I FREE DOWNLOAD @C (i) ৫}

Abstract: Parambassis waikhomi, a new species of glassfish from Loktak Lake, Chindwin basin in Manipur, northeastern India is distinguished from its congeners by the presence of 58-60 lateral line scales; two predorsal bones; a vertically elongated humeral spot; 24 vertebrae; maxilla reaching to $1 / 3$ of the orbit; 8.2 10.9 interorbital width; four preorbital ridge, 11 preorbital edge, six supraorbital ridge, 18 serrae at lower edge of preoperculum, 24 serrae at hind margin of preoperculum. The species differs from its nearest congener $P$. ranga by the presence of 9-10 (vs. 12-13) pectoral fin rays and 19-20 (vs. 22-28) gill rakers.

Keywords: Chindwin basin, Glass-perch, India, new species

from India, viz., $P$. baculis, $P$. dayi, $P$. lala, $P$. ranga and $P$. thomasi, three from Sumatra and Borneo, viz., $P$. apogonoides, $P$. macrolepis, and $P$. wolffi, another three from Myanmar, viz., $P$. pulcinella, $P$. tennaserimensis, and $P$. vollmeri, and the last one $P$. siamensis is from Malaysia and Chao Phraya namely. Sen(1995) reported three ambassid fishes from Meghalaya, viz., Chanda nama, Pseudambassis baculis (now Parambassis: see Roberts 1989) and P. ranga. Vishwanath et al. (2007) reported four ambassids from northeastern India, viz., Chanda nama, Parambassis baculis, $P$. lala and $P$. ranga. Recently, Geetakumari (2012) also described Parambassis bistigmata from northeastern India. The collection of fishes from Chindwin drainage of Manipur included an undescribed species which is herein described as Parambassis waikhomi sp. nov.

\section{Materials and Methods}

Measurements were made point to point with dial calipers to the nearest $0.1 \mathrm{~mm}$ and expressed as percentages of standard length (SL). Counts and measurements were made on the left side of specimens under a PC-based binocular stereozoom microscope (Olympus SZ40) with transmitted light. Methods for counts and measurements follow Kottelat (2003). Terminology for cephalic serration follows FraserBrunner (1955). Clearing and staining of specimens 
for osteology followed Hollister (1934). Identification and nomenclature of bones and vertebral counts followed Greenwood (1976). Materials examined in this study are deposited in Research Centre Manipur Museum of Fishes (RCMMF).

\section{Parambassis waikhomi sp. nov.} (Figs. 1-3, Image 1)

urn:lsid:zoobank.org:act:29454ED6-D57A-403C-9E4E-1791FC8121A1

\section{Type material}

Holotype: 19.xi.2011, 33.5mm SL, Chindwin basin, Loktak Lake, Manipur State, India, 24033'29'N \& 93048'58"E; coll. Bimol Singh (RCMMF-1).

Paratypes: 16 ex., $31.5-39.8 \mathrm{~mm} \quad \mathrm{SL}$; same collection data as holotype (RCMMF-2-17). 3 ex., 34.2-36.3 mm SL; dissected, cleared and stained for osteology (RCMMF-18-20).

\section{Diagnosis}

Parambassis waikhomi sp. nov. can be distinguished from all its congeners by the following combination of characters: 58-60 lateral line scales; 9-10 pectoral fin rays; 19-20 gill rakers; two predorsal bones; presence of a vertically elongated humeral spot; maxilla reaches to $1 / 3$ of the orbit; $8.2-10.9$ interorbital width; four preorbital ridge; 11 preorbital edge; six supraorbital ridge; 18 serrae at lower edge of preoperculum; 24 serrae at hind margin of preoperculum.

\section{Description}

Morphometric data and counts are presented in Table 1. Body laterally compressed, dorsal and abdominal profiles convex rising steeply from occiput to base of first dorsal fin, then gently sloping posteriorly. Eyes large, its margin free. Gill membranes free from isthmus; six branchiostegal rays. First branchial arch with 19-20 gill rakers. Two predorsal bones.

Nasal spine present. Preorbital ridge with 4-5 retrorse spine-like serrae and partly hidden in skin; preorbital edge with 11-12 distinct, exposed serrae projecting ventrally. Suborbital ridge not serrated. Supraorbital ridge with 5-6 retrorse serrae, partly subderminal. Preopercular ridge absent. Lower edge of preoperculum with 18-19 serrae, posteriormost ones largest; hind margin of preoperculum with 24-25 minute denticulations; interoperculum smooth. (Fig. 1).

Body covered by scales, except in predorsal area.

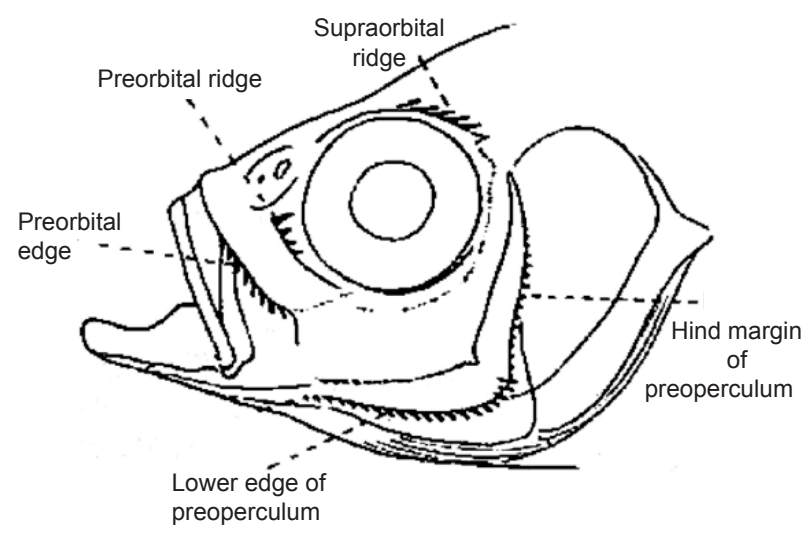

Figure 1. Cephalic serration of Parambassis waikhomi, 36.3mm SL (RCMMF-19)

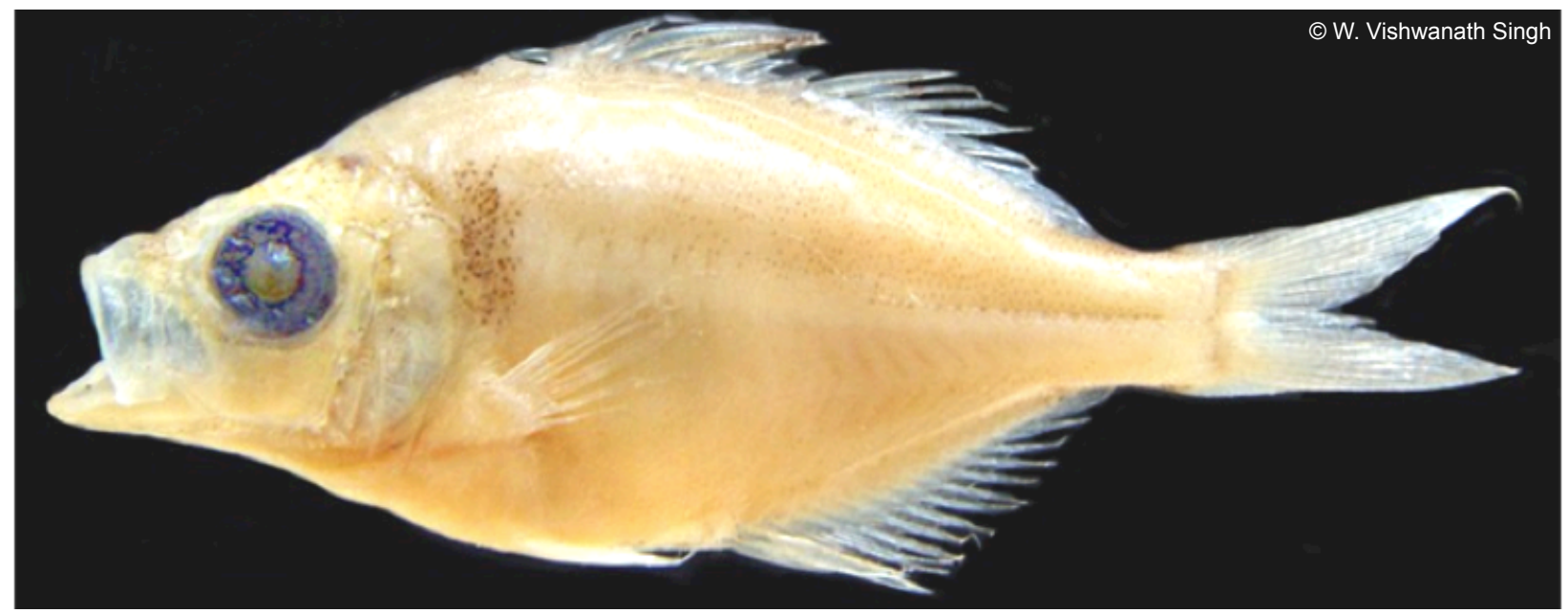

Image 1. Left lateral view of Parambassis waikhomi (RCMMF-16), $31.5 \mathrm{~mm} \mathrm{SL}$ 
Table 1. Morphological characters of Parambassis waikhomi sp. nov.

\begin{tabular}{|c|c|c|c|c|c|}
\hline \multirow{2}{*}{ Characters } & \multirow{2}{*}{ Holotype } & \multicolumn{4}{|c|}{ Paratypes $\mathrm{N}=19$} \\
\hline & & Mean & Min. & Max. & S.D. \\
\hline Standard length (mm) & 33.5 & 35.7 & 31.5 & 39.8 & 2.4 \\
\hline \multicolumn{6}{|l|}{ In \% SL } \\
\hline Head length & 34.6 & 39.3 & 30.9 & 47.7 & 4.6 \\
\hline Predorsal length & 42.5 & 42.6 & 39.0 & 46.1 & 2.1 \\
\hline Preanal length & 15.6 & 19.8 & 15.3 & 24.3 & 2.6 \\
\hline Body depth & 37.9 & 37.9 & 35.4 & 40.4 & 1.6 \\
\hline Depth of caudal peduncle & 11.6 & 11.1 & 9.9 & 12.2 & 0.8 \\
\hline Length of caudal peduncle & 11.5 & 13.9 & 11.5 & 16.3 & 1.4 \\
\hline Body width & 13.3 & 13.4 & 10.5 & 16.2 & 1.6 \\
\hline Snout length & 9.4 & 9.7 & 7.8 & 11.5 & 1.2 \\
\hline Eye diameter & 12.3 & 11.5 & 10.2 & 12.7 & 0.9 \\
\hline Interorbital width & 9.5 & 9.6 & 8.2 & 10.9 & 0.8 \\
\hline Length of dorsal-fin base & 43.7 & 45.1 & 42.6 & 47.6 & 1.7 \\
\hline Length of anal-fin base & 32.3 & 31.3 & 28.6 & 34.0 & 1.6 \\
\hline Length of pelvic-fin spine & 18.0 & 17.7 & 15.3 & 20.1 & 1.3 \\
\hline Length of pectoral fin & 25.7 & 24.6 & 21.5 & 27.7 & 2.1 \\
\hline Length of upper caudal-fin lobe & 28.2 & 29.1 & 26.2 & 32.0 & 2.1 \\
\hline Length of median caudal-fin rays & 15.5 & 15.9 & 13.2 & 18.6 & 1.7 \\
\hline Length of lower caudal-fin lobe & 28.3 & 27.3 & 23.4 & 31.1 & 2.3 \\
\hline
\end{tabular}

Head naked, except 3-4 (4) scale rows on cheek. Lateral-line scales $58-60 ; 10$ rows of scales between lateral line and base of last dorsal spine; $1 / 2$ 9/1/9 $1 / 2$ scale rows in transverse line across caudal peduncle. First dorsal fin with seven spines, second one longest; second dorsal fin continuous with first with one spine and 14-15 (14) branched rays (last two rays inserted on same pterygiophore counted as one). Anal fin with three spines, third one longest, with 14-15 (14) branched rays. Pelvic fin with one spine and five branched rays. Pectoral fin with 10 rays. Caudal fin with 11+11 branched rays, vertebrae 24 (3).

Dentition: Many small conical teeth are embedded in the premaxilla where the teeth in the outer row is larger. Dentary is also with many small villiform teeth where 5-6 canine-like teeth are randomly arranged medially on each side (Fig. 2).

Coloration: In 10\% formalin: head and body background creamish. A faint blackish axial streak on body, darker posteriorly. Each scale margins outlined by indistinct melanophores. A vertically elongated humeral blotch, more or less continuing a vertically elongated triangular blotch immediately in

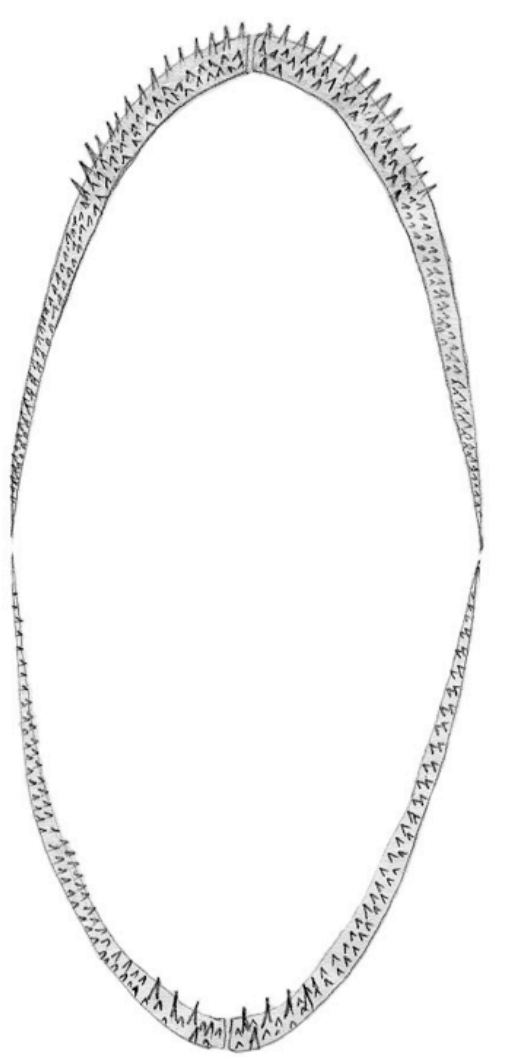

Figure 2. Dentition of Parambassis waikhomi, $36.3 \mathrm{~mm} \mathrm{SL}$ (RCMMF-19) 


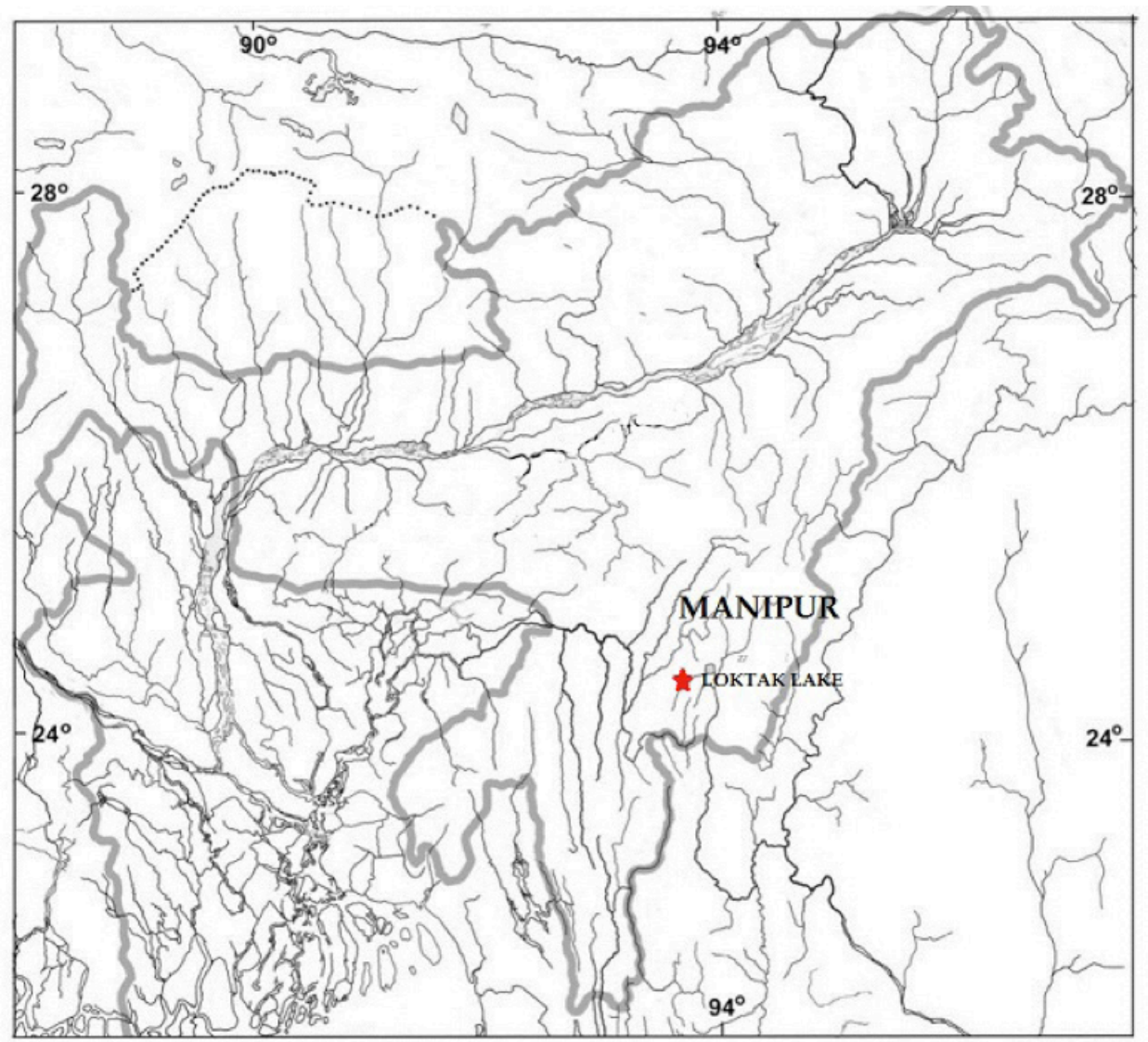

Figure 3. Distribution map of Parambassis waikhomi

front of first dorsal-fin origin. Second to fourth spine of first dorsal with a decorative distinct blackish outer margin, second dorsal hyaline. Pectoral, pelvic and anal fins hyaline. Caudal fin with a series of unevenly distributed dots between each ray.

Live colours: Pattern as in preserved specimens, general colouration yellowish to silvery, body semitransparent with yellowish-chin.

\section{Etymology}

This new species is named after Prof. Waikhom Vishwanath honouring his contributions to the ichthyology of freshwater fishes of northeastern India.

\section{Distribution}

Presently known from the Loktak Lake, Chindwin basin, Manipur, northeastern India (Fig. 3).

\section{Discussion}

Parambassis waikhomi sp. nov. is distinguished from its nearest congener Parambassis ranga in having 19-20 (vs. 22-28) gill rakers, 9-10 (vs. 12-13) pectoral fin rays. Presence of six supraorbital spine (vs. absence), more number of moderately large serrae in preorbital ridge (11-12 vs. 7) and absence of serrae (vs. presence of 8 large serrae) in preopercular ridge.

Parambassis waikhomi sp. nov. differs from $P$. apogonoides, $P$. dayi, P. macrolepis, $P$. siamensis, $P$. thomasi, and $P$. wolffii by the presence (vs. absence) of a humeral spot. It differs from $P$. apogonoides, $P$. dayi, P. macrolepis, $P$. siamensis, and $P$. thomasi, $P$. wolffi by the absence (vs. presence) of predorsal scales. It is also distinguished from $P$. apogonoides, $P$. dayi, P. thomasi, $P$. wolffii and $P$. vollmeri in having more scale (58-60 vs. $34-50)$ in the lateral series. It differs from $P$. vollmeri in having more gill rakers (19-20 vs. 13-16), and the absence of serrae (vs. presence of 11 serrae) in the preopercular ridge. It also differs from $P$. bistigmata in the absence (vs. presence) of two distinct black spots on either side of the anal fin origin connected by a narrow black curved line.

Parambassis waikhomi sp. nov. differs from $P$. baculis in having more gill rakers (19-20 vs. 12-15), 
less scales in lateral series (58-60 vs. 80-100), less pectoral fin rays (9-10 vs. 13). It differs from P. lala in having less scales in lateral series (58-60 vs. 66), absence of serrae in the preopercular ridge (vs. 9 large serrae), absence of vertical dark bands (vs. presence of two broad vertical dark bands) in the flanks.

The new species is distinguished from $P$. tennaserimensis in having more scales (58-60 vs. 53) in the lateral series, more serrae in the preorbital edge (11 vs. 5) and more serrae in lower edge of preoperculum (18 vs. 9). It differs from P. pulcinella in (absence vs. presence) of a conspicuous compressed hump in front of first dorsal-fin origin and in having more number of scales in lateral series (58-60 vs. 51-53).

Parambassis baculis and $P$. ranga were previously included under the genera Pseudambassis (Talwar \& Jhingran 1991). Later in 1994, Roberts transferred them as the generic characters fit that of Parambassis.

According to Roberts (1994), Parambassis can be divided into two species groups; one usually without a humeral spot and with short dorsal and anal fins (each with only 9-11 soft rays) and another usually with a humeral spot and with long dorsal and anal fins (each 12-17 soft rays). He felt, however, that these groups were not monophyletic. Parambassis waikhomi sp. nov. apparently belongs to the later group.

Some of the glass fishes are widely distributed in different basins. Roberts (1994) stated that glassperches are mostnumerous in India and Borneo. The widespread nature of occurrence could be attributed either to the ornamental trade and widespread introductions or the 'widespread' species could be species complexes. However, the populations of various species in many basins need examination and verification.

\section{Comparative materials}

Parambassis baculis: MUMF Uncat., 5 ex., 38.5$42.6 \mathrm{~mm}$ SL, India: Tripura, Agartala.

Parambassis bistigmata: MUMF/Per-105, 39.3mm SL; India: Arunachal Pradesh state: Ranga River, Kimin station, Brahmaputra drainage.

Parambassis lala: MUMF/Per/G-3-7, 5ex., 38.038.5 mm SL, India: Assam: Silchar.

Parambassis ranga: RGUMF-0147, 1ex., $40.2 \mathrm{~mm}$ SL, India: Arunachal Pradesh: Kimin. MUMF/ Per/G-8-11, 4ex., 38.0-40.5 mm SL, India: Manipur: Tamenglong: Leimatak River.

Published informations used for comparison: Roberts (1994) for $P$. apogonoides, $P$. dayi, $P$. macrolepis, $P$. siamensis, $P$. thomasi, $P$. vollmeri, $P$. wolffii and Kottelat (2003) for P. pulcinella

\section{REFERENCES}

Fraser-Brunner, A. (1955). A synopsis of the centropomid fishes of the subfamily Chandidae, with description of a new genus and two new species. Bulletin of Raffles Museum 25 (1954[1955]): 185-213.

Geetakumari, K. (2012). Parambassis bistigmata, a new species of glassperch from north-eastern India (Teleostei: Ambassidae). Zootaxa 3317: 59-64.

Greenwood,P.H.(1976). Areview of the family Centropomidae (Pisces: Perciformes). Bulletin of the British Museum (Natural History) 29(1): 1-81.

Hollister, G. (1934). Clearing and dyeing fish for bone study. Zoologica 12: 89-101.

Kottelat, M. (2003). Parambassis pulcinella, a new species of glassperch (Teleostei: Ambassidae) from the Ataran River basin (Myanmar), with comments on the familygroup names Ambassidae, Chandidae and Bogodidae. Ichthyological Exploration of Freshwaters 14(1): 9-18.

Roberts, T. R. (1989). The freshwater fishes of western Borneo

Key to species of the genus Parambassis of India

$1 . \quad$ Presence of humeral spot

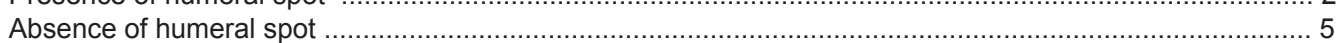

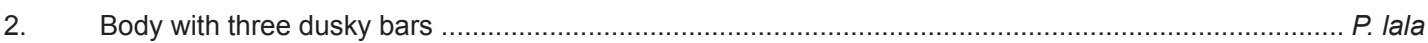

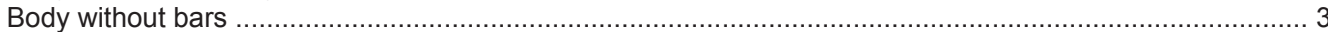

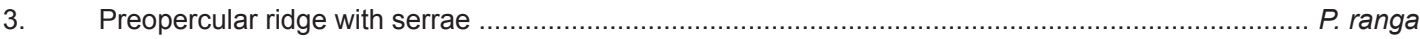

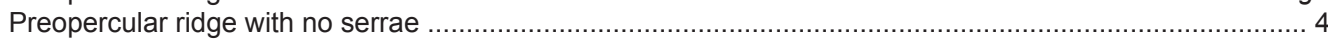

4. Presence of 2 distinct black spots on either side of the anal fin .............................................. P. bistigmata

Absence of 2 distinct black spots on either side of the anal fin ........................................................ 5

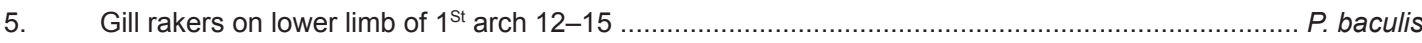
Gill rakers on lower limb of $1^{\text {st }}$ arch 19-20 ................................................................ P. waikhomi sp. nov.

6. Anal fin scale sheath with only row of scale .............................................................................. dayi

Anal fin scale sheath with two row of scales ........................................................................ P. thomasi 
(Kalimantan Barat, Indonesia). Memoirs of the California Academy of Sciences 14: i-xii+1-210.

Roberts, T.R. (1994). Systematic revision of tropical Asian freshwater glassperches (Ambassidae), with descriptions of three new species. Natural History Bulletin of Siamese Society 42(1994 [1995]): 263-290.

Sen, N. (1995). Pisces, state fauna of Meghalaya. Zoological Survey of India 1: 483-606.
Talwar, P.K. \& A.G. Jhingran (1991). Inland Fishes of India and Adjacent Countries. Oxford and IBH Publishing Co. Pvt. Ltd., N. Delhi, 1991, 2 vols, xix +1158.

Vishwanath, W., W.S. Lakra \& U.K. Sarkar (2007). Fishes of North East India. National Bureau of Fish Genetic Resources, Lucknow, India, 264pp. 